\title{
Grassroots Participation in Decision-Making Process and Development Programmes as Correlate of Sustainability of Community Development Programmes in Nigeria
}

\author{
I. Adekeye Abiona ${ }^{1} \&$ W. Niyi Bello ${ }^{1}$ \\ ${ }^{1}$ Department of Adult Education, University of Ibadan, Ibadan, Nigeria \\ Correspondence: I. Adekeye Abiona, Department of Adult Education, University of Ibadan, Ibadan, Nigeria. \\ E-mail: keyeabiona@gmail.com
}

Received: November 23, 2012 Accepted: January 30, 2013 Online Published: February 25, 2013

doi:10.5539/jsd.v6n3p47

URL: http://dx.doi.org/10.5539/jsd.v6n3p47

\begin{abstract}
This study examines grassroots participation in decision-making process and sustainability of community development programmes in Nigeria. In spite of many policies on development programmes by the government, the physical and socio-economic conditions in most of communities in Nigeria do not seem to have improved significantly. The descriptive survey research design was used. The stratified random sampling technique was adopted to select 1,984 respondents (community leaders (266); change-agents (569); members of community development associations $(1,022)$ and political representatives (127) in nine communities each from Osun (964) and Kwara states $(1,020)$ ). A questionnaire: Grassroots Participation in Decision-making Process and Programmes Scale (GPDPPS) and Community Development Sustainability Questionnaire (CDSQ) were used for data collection. One research question was answered and two hypotheses tested at 0.05 level of significance. Data were analysed using Pearson's Product Moment Correlation. Results showed that there is significant relationship between grassroots participation in development programmes $\left(\mathrm{r}=.335^{* *} ; \mathrm{p}<0.05\right)$; decision-making process $\left(\mathrm{r}=.210^{* *} ; \mathrm{p}<0.05\right)$ and sustainability of development programmes. Furthermore, political instability, leadership problems, communal clashes, inadequate funding and poor accountability impeded sustainability. It was recommended that the problems of political instability, leadership, inadequate funding, communal clashes, accountability, and communication gap should be considered in grassroots decision making in development programmes.
\end{abstract}

Keywords: community development, sustainability, participation, decision-making

\section{Introduction}

The transformation of communities to improve their lives has become the main challenge to the economic and social development efforts of developing nations like Nigeria. This challenge arises from the need to promote the welfare of the people of the rural and urban communities so that they could acquire a better standard of living in their homes (Onabanjo, 2004). Many countries, especially, the developing countries such as Nigeria have embarked on different pragmatic programmes to make better the lots of the citizens at the grassroots, particularly, in the areas of physical development of communities. The rate of development of any community is facilitated by the people's recognition of the need for self-help and their readiness to take necessary actions towards achieving the development. It should be noted that every community in Nigeria needs development, especially, in terms of social amenities (Adegboye, 2005).

Community development has been a veritable tool for mobilizing and integrating people into contributing meaningfully to the growth of their areas in particular and the process of national development in general (Onabanjo, 2004; Abiona, 2009). This awareness has led many communities to embark on activities that could transform their local and rural environment into urban and better developed settings. Osuji (1992) pointed out that the Nigerian communities have employed communal efforts as the mechanism for mobilizing community resources to provide physical improvement and functional facilities in their localities in the social, political and economic aspects of their life. Thus, physical development of a community is an indicator that development has taken place. 
Community development is an age-long practice that could be traced to the tradition before the advent of colonial administration. The traditional community development efforts evolved voluntary routine exercise in which able-bodied, young and old participated in the traditional tasks of clearing road-paths and compounds for the protection of land and property. However, with the growing complexity of our society, coupled with increase in population and urbanization, with attendant high taste of the people for modern basic and social amenities, community development witnessed a significant leap and become more complex in process, form and scope in recent years. Its scope and form witnessed rapid transformation from mere provision of rudimentary tasks to a more complex task of supplementing governments' efforts in the provision of basic and social services (Akinyemi, 1994; Abiona, 2009). Some of the community development programmes include rehabilitation of roads, skill acquisition programmes, community education programmes, community security programmes among others (Anyanwu, 1991; Abiona, 2009). It also involves social services and activities like organization of literacy classes, youth forum, cultural and aesthetic shows by individuals and interest groups within the various communities.

The vast majority of the populace is still living, devoid of both basic and social amenities. Coupled with this is the acceptance of the fact that meaningful development can only take place when the people are well mobilized for community action. In a bid to foster sustainable community development at the grassroots, government at all levels over the years have intervened in the sustenance and strengthening of meaningful and pragmatic community development programmes (Onabanjo, 2004).

In spite of government efforts to achieve meaningful development at the grassroots, many communities are still in pathetic state of stagnation and neglect. On the part of the government sponsored projects, many community projects were abandoned half-way due to poor logistics and financial constraint, poor planning and management. As a result of this, the community development departments are not stable in a ministry but are tossed from one ministry to the other depending on the wishes and caprices of government in power. Lack of consensus as to the proper place of community development in the governmental machinery formed a larger problem in the low priority accorded to community development. Some problems were noticed to have impeded community development programmes such as lukewarm attitude to maintenance, exodus of people from rural to urban area, wrong belief of people that government was capable and should provide all their needs for them, inadequate funding on the part of individual members, problem of illiteracy, communal clashes among others (Akinyemi, 1990; Otite, 2002).

The under-development nature of rural communities in Nigeria is evident rather than a mere expression. It is observed that many states and local governments are deficient in technological infrastructure or in all the good things of life: electricity supply has degenerated, pipe-borne water supply is non-existent, schools are ill-equipped while other social services have drastically degenerated with many of the hospitals now death centers rather than medical centers while many of the roads are now in deplorable condition. The number of beggars along the streets has increased drastically and its attendant general restiveness has become a serious menace to both social and economic development (Obanigwe, 1991; Abiodun, 1998; Maureen, 2005). Corroborating this view, a World Bank report (1995) cited in Ugwu (2000) observed thus: A large number of people in Nigeria in urban area do not have enough income to meet their needs, about $21 \%$ of the urban population- 85 million people were estimated to be living below the poverty line. In 1992/93, about 1 million people were classified severally poor. Their cash income is insufficient to cover minimal standards of food, water, fuel, shelter, medical care and school fees.

Community development involves efforts of both government and communities. However, in Nigeria, many communities still believe that developmental programmes are sole responsibility of government in power. Projects provided solely by the government without involving the people in many communities could not be sustained because there is no commitment on the part of the people. In such an instance, there is no link between sustainability of projects provided by the government and the interest of the people because people are not involved in decision making. Members of the community should have interest in the programme that affects their welfare and participate actively in the identification of their needs, planning, execution of programmes, utilization and evaluations. Thus, participation yields greater interest in sustainability (Abiona, 2009). For sustainability of community development programmes to be ensured Abiona (2009) identified some key elements of programmes sustainability among which include: programme should be people oriented, the need for stability of government and stable policies; transparency and accountability in all sectors; equal access to resources; and effective political system; recognition and involvement of local institutions in development programmes. 
It has been observed from many literatures that community development programmes have been marred by many problems such as financial constraint, nonchalant attitude to maintenance, marginalization of communities due to decentralisation, abandoned project, poor mobilization, poor planning and maintenance among others. Also, it has been observed from many studies that community development programmes have not been given prominence by the government and citizens in many communities in Nigeria (Akinyemi, 1994; Adedokun, 1998; Otite, 2002; Akoroda, 2012). Essentially, most people in Nigeria believe that it is the responsibility of government to provide, maintain and sustain all infrastructures.

\subsection{The Concept of Sustainability of Development}

Sustainable development connotes development that endures and last; one that will not roll back or recede, even, in the face of threatening reversal waves (Omotola, 2006). It is development that can guarantee the protection of the environment and resources today and tomorrow. It is also one that is self-sustaining and meets the need of present and future generations (World Bank, 2001). Sustainable development is multi-dimensional and seeks to promote spatial, social, political, economic and psychological linkages, not only among the different sectors of the economy but also, among the different regions of the national economy. As such, it encourages equitable distribution of wealth rather than merely emphasizing Gross National Products (GNP) alone. Sustainable development connotes a programme of development which caters for immediate and future generations in a community. It denotes maintenance of already established statues to accommodate changes and planning steady growth in the community (Omotola, 2006).

The principle underlying the concept of sustainability is that conventional approaches to development would gradually be changed to focus on people as the ultimate target of development. Development should be based on the needs and vision of the people through citizen participation and self help. Babashola (1998) stated that it depicts a vision of development of people, largely by their own effort as participants, stakeholders and beneficiaries. The concept also emphasizes cognizance of the natural environment, socio-cultural, economic and political structure, participation, the institutional framework and other factors of sustainability that can make development meaningful.

Therefore, sustainable rural transformation encompasses several aspects or dimensions which Eboh, Okoye and Ayich (1995) itemize as economic, human, environmental, technological and institutional. Sustainable development would require simultaneous progress along each of these dimensions. Sustainable development along the economic dimension would mean the commitment of resources towards continued increases in rural outputs, productivity and incomes. It entails tackling rural-urban disparity in physical infrastructure and in economic opportunities by making economic resources like credit, land and other productivity capital available to rural producers, adequately and timely. Sustainable development in environmental dimensions means protecting the natural resources (including land or soil, forests, water bodies and wild lives) while they are being presently exploited so that the future generations can meet their needs from the same resources. Sustainable development is a nullity without a strong human capital base. Investing in human capital needed for continuing rural development and enable fuller use of human resources available in the rural areas. By improving education and health services, combating hunger and alleviating poverty, the social well-being and welfare conditions of rural people will significantly be better.

Institutional dimensions of sustainable development give room for innovations that create and maintain rural growth which include the empowerment of local groups, indigenous associations and community-based organization to ensure their full, direct and active involvement in rural development in decision making, planning and implementation. Sustainable development cannot be helped by the introduction of exotic, inappropriate, unreachable and incompatible techniques, tools or implements and practices (Akintayo \& Oghennekohwo, 2004).

Sustainable development means the powerless getting empowered. As power comes through unity - development means the poor getting organized to fight for their rights, to tilt the balance of power in their own favour. A major contribution to sustainability should come from the grassroots organizations, whereby programme beneficiaries gradually assumed increasing responsibility for project activities during decision making, implementation and particularly following completion. These grassroots should, for their growth possess some forms of decision autonomy and self-reliance: a measure of beneficiary control over measurement of the programme and the continue alignment of the programme activities with the needs of the beneficiaries (Akinboade, 1994). 


\subsection{Grassroots Participation in Development Programmes and Sustainability of Community Development Programmes}

The term citizen participation has become rhetorical in recent times. Different people in different contexts use it to connote different things. The following connotes people's participation as identified by Singh (1992) based on their experience:

a. attending meetings, call to discuss matters relating to the design, implementation, monitoring and evaluation of natural resources management;

b. contributing money, labour, or both to activities /projects of common interest to the group/ community;

c. seeking new knowledge and information and sharing it with other members of the group/community as well as within the project authority concerned;

d. following the rules and regulations set by the group/community/organization in consultation with the local people;

e. adoption of technologies and practices recommended by the project authority;

f. abstaining from doing any harm or damage to the common property or asset created as a result of participatory efforts;

g. serving on the joint management committees constituted by the project authority for natural resources management.

Egenti (2001) identifies some of the objectives and functions of participation which include making local wishes known, generating development ideas, providing local knowledge, and testing proposals for feasibility and improving them. Others are increasing the capability of communities to handle their affairs and to control and exploit their environments, demonstrating support for regime, doing what is required of government to be done, extracting, developing and investing in local resources (labour, finance, and managerial skills among others) and promoting desirable relationships between people, especially through cooperative work. Participation is about change that is effective, authentic and enduring and is the kind of change that is talked about when nodding towards notions like sustainability.

In the context of organizational development, Anyanwu (1992) refers to citizens participation as an active process whereby beneficiaries influence the direction and execution of development projects rather than merely receiving a share of the project benefits. Thus, it can be said that citizen participation in organizational development programmes entails the involvement of the people or their representatives in the formulation and development of proposals, planning of programmes and its implementation. Citizen participation in development programme is therefore an obvious strategy for programme success, as it is a powerful tool for mobilizing new and additional resources within the organization (Anyanwu, 1992). The principle of citizen participation implies, therefore, that community members have to supply the necessary and needed stimulus for programme's success. Paul (1987) observed that citizen participation is mainly used to achieve effectiveness, efficiency and cost sharing. A consideration of these definitions of citizen participation and the extent to which project implementation has incorporated participation into project strategy are indications of the minimal practical application of the concept in project design and implementation.

Osuji (1992) perceives community participation in relation to development as the involvement of members of communities in all stages of decision making relating to development programmes in their areas. What this means in effect is that development programmes and projects should not be imposed on the people who are supposed to be the beneficiaries of development efforts. Beneficiary populations should not be made passive recipients of services; rather they should take part in all activities concerned with the development of their areas.

\subsection{Components of Community Development Programmes in Nigeria}

In order to achieve a holistic community development, some programmes were identified in the National Community Development Policy for Nigeria among which include:

i. Physical infrastructure development programmes such as construction of roads, rehabilitation of roads, construction of culverts, building market stalls, modern market, electricity, drainage facilities and palaces among others;

ii. Social development programmes which include town hall, library, Television viewing centers, school bus facilities, sports facilities, juvenile delinquency rehabilitation centers, day care center, security post among others; 
iii. Health programmes which include campaign against HIV/AIDS, cerebral meningitis, water-borne diseases, bird flu among others;

iv. Educational programmes that involve changing the mental capacity of the people such as literacy campaign, vocational training centers, post-literacy centers, building of schools among others;

v. Economic programmes that involve formation of co-operative societies, community banking system among others;

vi. Communication development programmes such as postal agencies, telephone centers, internet services among others;

vii. Environmental protection programmes such as garbage collection, community latrine, community parks among others;

viii. Human development activities such as community mobilization, public enlightenment among others;

ix. Community security and conflicts management which include neighborhood protection (vigilante), local system of conflicts resolution, Police community relation commitees among others;

x. Water supply programmes such as sinking of boreholes, construction of walls, construction of earth dams, pipe-borne water among others. (Anyanwu, 1991; Community Development Agency, 2007; Abiona, 2009).

\subsection{Decision-Making Process and Sustainability of Community Programmes}

Decision-making process is one of the most important roles of the community stakeholders. Every administrative act, whether it concerns government officials, change agent, programmes, services, or resources, requires taking decision. Decision-making precisely is an act of choice between alternative causes of action. To be able to decide what action to take on any programme, the community stakeholders need to know, not only the various alternative action that exist, but also what type of decision to make, who should make the decision, how the decisions should be made and how decisions would be carried out effectively. Felt-need of the people is determined when citizens come together to take decision of the most urgent or pressing need of all the needs in the community (Abiona, 2009). Decision- making process is a strong factor which determines the nature of leadership, the level of authority, the span of control, the degree of participation and co-operation, the level of supportiveness, and the possibility that decision should be carried out.

Decision-making is one of the defining characteristics of leadership. It is not that people do not have the capacity to make high-quality decisions in them. Decision-making is a distinctly human activity. Good decision-making requires, not only knowing the facts, but understanding the limits of your knowledge. The most valuable insights are often found in exploring uncertainties and "disconfirming" information. The effective decision does not, as so many texts on decision-making proclaim, flow from a consensus on the facts. The understanding that underlies the right decisions grows out of the clash and conflict of divergent opinions and out of the serious consideration of competing alternatives. Leaders should focus on creating the dynamics that support organizational decision, quality-on putting in place a decision framework and process that support organizational decision quality-rather than raking through the detailed minutia of specific decisions. A high quality decision process highlights the frame, potential alternatives, and key assumptions that drive value. This allows leaders to spend their time declaring the right decisions, providing a set of common criteria, and testing the key assumptions of each decision.

There are several ways of describing or analyzing decision making. But, generally, the major issues in decision making analysis and study concern the type of decision, who makes or should make decisions, at what level and how decisions are made.

\subsection{Types of Decisions}

There are various ways of describing the types of decision. Oyelami (2007) cited Gulbert (2000) classified decision under: (a) organization and personal decision; (b) basic and routine decisions; and (c) programmed and non programmed decisions. Olaniyi (1994) in Oyelami (2007) categorized decision under "intermediary" decisions (coming from top management downwards), "appellate" decision (coming from any member of the group as a result of insight or creativity).

(a) Organization and Personal Decisions

Olaniyi (1994) cited in Oyelami (2007) stresses that decisions made by the administrator may be organization or personal decision. An organization decision is made for a developing country where the majority live in rural areas. The success of democracy hinges principally on rural dwellers' capacity to gain power and achieve greater 
possibilities to participate in policy and decision-making process. Indeed, in the search for new appropriate institutional framework for national democratizing, rural socio-economic settings must be understood and assessed. It could be argued, therefore, that if rural dwellers are to play an active and meaningful role in national governance and development, it becomes imperative that they need to be effectively mobilized, motivated and invigorated.

\subsection{Research Question}

RQ1: What factors impede decision making and sustainability of community development programmes through grassroots participation in development programmes in Osun and Kwara States?

\subsection{Research Hypotheses}

The following null hypotheses were tested for the purpose of study:

$\mathrm{Ho}_{1}$ : There is no significant relationship between grassroots participation and sustainability of community development programmes.

$\mathrm{Ho}_{2}$ : There is no significant relationship between decision -making process and sustainability of community development programmes

\section{Methodology}

Descriptive survey research design was adopted for the study. This method described, examined, and analyzed the variables of grassroots participation, decision-making process and its influence on sustainability of community development programmes.

The population of this study comprised members of community development associations, community leaders, change agents and political representatives in selected nine communities each from Osun and Kwara States in Nigeria, based on the available records which show arrays of participation in community development projects among the inhabitants.

The multi-stage sampling procedures were adopted for this study. The first stage involved cluster sampling technique, whereby two states were selected purposively, namely; Osun state from South-West and Kwara state from North-central geo-political zones respectively. The second stage involved the stratification of these states into six zones along the existing senatorial districts along which three senatorial districts were selected from each of the state. To ensure adequate representation, three local government areas were selected from each senatorial district, which resulted to nine local governments from each state. The selection of the local government areas were based on the level of arrays of community development projects.

The third stage involved a purposive random sampling of specific respondents in proportion to their participation in community development programmes along the basis of being a member of community development association, change agents, community leaders and political leaders. The proportion sample size was $50 \%$ from population of 4,100 and the total sample for the study was 2,050 respondents.

Two sets of questionnaire were employed in this study for data collection. The first set of questionnaire was tagged Grassroots Participation Assessment Scale (GPAS) while the second set was tagged Community Development Sustainability Questionnaire (CDSQ). The instruments were subjected to validity and reliability test.

Data were analysed using Pearson's Product Moment Correlation and t-test. The hypotheses generated were tested at 0.05 level of significance.

\subsection{Hypothesis One}

$\mathrm{Ho}_{1}$ : There is no significant relationship between grassroots participation and sustainability of community development programmes. 
Table 1. Relationship between grassroots participation and sustainability of community development programmes

\begin{tabular}{lcccccc}
\multicolumn{1}{c}{ Variable } & Mean & Std. Dev. & N & R & P & Remark \\
\hline $\begin{array}{l}\text { Grassroots participation in development } \\
\text { programmes }\end{array}$ & 20.3649 & 5.8966 & 1984 & .335 & .000 & Sig. \\
$\begin{array}{l}\text { Sustainability of Community } \\
\text { Development programmes }\end{array}$ & 20.3523 & 4.3627 & & & & \\
\hline
\end{tabular}

Sig. at. $\mathrm{P}<0.05 ; \mathrm{r}=.335$.

It is shown in Table 1 that there was a significant relationship between grassroots participation and sustainability of community development programmes $(r=.335 ; \mathrm{p}<0.05)$.

The null hypothesis is therefore rejected and the alternative hypothesis formulated is accepted. This shows that grassroots participation has influence on sustainability of community development programmes in Osun and Kwara States, Nigeria.

\subsection{Hypothesis Two}

$\mathrm{Ho}_{2}$ : There is no significant relationship between decision-making process and sustainability of community development programmes in Osun and Kwara States, Nigeria.

Table 2. Relationship between decision-making process and sustainability of community development programmes in Osun and Kwara States, Nigeria

\begin{tabular}{lcccccc}
\hline Variable & Mean & Std. Dev. & N & R & P & Remark \\
\hline Decision-making Process & 35.8447 & 5.5015 & & & & \\
Sustainability of Community & 20.3523 & 4.3627 & 1984 & .210 & .000 & Sig. \\
Development Programmes & & & & & &
\end{tabular}

Sig. at .p $<0.05 ; \mathrm{r}=.210$.

It is shown in Table 2 that there was significant relationship between decision-making process and sustainability of community development programmes in Osun and Kwara States, Nigeria $(\mathrm{r}=210 ; \mathrm{p}<0.05)$. The null hypothesis formulated is rejected. Consequently, the alternative hypothesis is retained. This means that when the data was subjected to Pearson correlation test, it shows that decision-making process has influence on sustainability of community development programmes in Osun and Kwara States, Nigeria.

\section{Result of Research Question}

RQ1: What factors affect sustainability of community development programmes through grassroots participation and decision-making process in Osun and Kwara States?

From Table 3, it was shown that communal clashes had significant relationship with sustainability of community development programmes $(\mathrm{r}=.136, \mathrm{p}<0.05)$. The findings revealed that communal clashes have impeded the level of sustainability in community development programmes, grassroots participation in development programmes and decision-making process in Osun and Kwara States.

Table 3 below shows that poor accountability and transparency affected sustainability of community development programmes $(\mathrm{r}=.121, \mathrm{p}<0.05)$. This study revealed that poor accountability and transparency impeded the sustainability of community development programmes through grassroots participation in development programmes and decision-making process in Osun and Kwara States.

On leadership problem, the result from Table 3 shows a significant correlation in leadership problem and sustainability of community development programmes between Osun and Kwara States $(r=.230, p<0.05)$. The findings revealed that leadership problem is one of the factors that impeded sustainability of community development programmes in Osun and Kwara States. 
Table 3. Correlation matrix showing the relationships between sustainability of community development, grassroots participation and decision-making process and communal clashes, poor accountability, leadership problems, political instability and inadequate funding

\begin{tabular}{lllllll}
\hline & $\begin{array}{l}\text { Sustainability } \\
\text { of community } \\
\text { Development }\end{array}$ & $\begin{array}{l}\text { Communal } \\
\text { Clashes }\end{array}$ & $\begin{array}{l}\text { Poor } \\
\text { Accountability }\end{array}$ & $\begin{array}{l}\text { Leadership } \\
\text { Problems }\end{array}$ & $\begin{array}{l}\text { Political } \\
\text { Instability }\end{array}$ & $\begin{array}{l}\text { Inadequate } \\
\text { funding }\end{array}$ \\
\hline $\begin{array}{l}\text { Sustainability } \\
\text { of community } \\
\text { Development }\end{array}$ & 1 & & & & \\
$\begin{array}{l}\text { Communal } \\
\text { Clashes }\end{array}$ & $.136^{* *}$ & 1 & & & \\
$\begin{array}{l}\text { Poor } \\
\text { Accountability }\end{array}$ & $.121^{* *}$ & $.303^{* *}$ & 1 & & & \\
$\begin{array}{l}\text { Leadership } \\
\text { Problems }\end{array}$ & $.230^{* *}$ & $.282^{* *}$ & $.550^{* *}$ & 1 & & \\
$\begin{array}{l}\text { Political } \\
\text { Instability }\end{array}$ & $.453^{* *}$ & $.199^{* *}$ & $.194^{* *}$ & $.063^{* *}$ & 1 & \\
$\begin{array}{l}\text { Inadequate } \\
\text { Funding }\end{array}$ & $.129^{* *}$ & $.945^{* *}$ & $.280^{* *}$ & $.257^{* *}$ & $.187^{* *}$ & 1 \\
Mean & 57.0832 & 22.8115 & 22.9758 & 21.8579 & 28.2203 & 28.2203 \\
S.D & 4.6865 & 2.5851 & 4.6456 & 4.1548 & 2.6147 & 25.9556 \\
\hline
\end{tabular}

Source: computed from field data @2011.

In Table 3 above, the result shows that there was a significant relationship between sustainability of community development programmes and problem of inadequate funding $(\mathrm{r}=129 ; \mathrm{p}<0.05)$. This implies that inadequate funding impeded sustainability of community development programmes.

On the issue of political instability, the result in Table 3 shows that there was a significant relationship between grassroots participation in development programmes and political instability in Osun and Kwara States ( $\mathrm{r}=453$, $\mathrm{p}>0.05$ ). This implies that political instability impeded the process of sustainability of community development programmes.

\section{Discussion of Findings}

From Table 1 above, it has been established in this study that grassroots participation in development programmes has facilitated sustainability of community development programmes in Osun and Kwara states. The result from Table 1 above is also in congruent with the findings of Adedokun (1998), Abiona (2009) and Akoroda (2012) that there a relationship between grassroots participation in development programmes and sustainability of community development programmes. Corroborating this finding, the research report of Akinyemi (1994) in Ondo state stressed that there is encouraging attitude in community participation among rural dwellers and further stressed that community participation has become a crucial factor in any meaningful development effort. Also, the research carried out by Egenti (2001) is in line with this study that there was a significant relationship between citizens' involvement in decision making, planning, implementation and evaluation stages in self- help projects for improved welfare of the people.

The findings in Table 2 above on grassroots participation in decision-making process also buttressed the experience in Nepal programmes (Nepal Development Programmes, 1998). It was discovered in Nepal programmes that democracy was practised through community development. The community comes together once in a month to discuss issues and share experiences, which is a powerful forum for expressing the needs of the villager (www.nnssd.net). The findings from this study revealed that community members were always involved in policy formulation and decision-making process for development purposes both in Osun and Kwara states.

The findings revealed that communal clashes have impeded the level of sustainability in community development programmes through decentralization in Osun and Kwara states. In most cases, communal clashes, 
resulting from land disputes, have been the major problems that impeded sustainability of community development programmes in Osun and Kwara states. These findings corroborate Otite (2003) which observed lacked of harmony and collaboration in Ekakpamire community of Delta States which affected the rate of development.

The findings revealed that many community leaders lack effective leadership and they are not loyal, accountable and transparent. Money contributed for development projects are diverted to personal account such that implementation, monitoring and sustainability of community development programmes were hindered. This finding is in line with the FGD carried out by Abisoye (2008) that problem of poor accountability was reported among the leaders at the local level and Abiona (2009) who stated that a major problem of community development is embezzlement of fund by leaders.

The findings of this study revealed that there was inadequate funding on the part of the community members to contribute towards projects implementation. However, lack of mutual trust discourages community people to contribute fund which has impeded decision making and sustainability of community development progammes through grassroots participation in development programmes. This study is consistent with that of Akinyemi (1990) which revealed that lack of finance constituted the major obstacles affecting community development activities investigated in Ondo State. The finding of this study is also in line with the findings of Otitte (2002) on the issue of finance, that the respondents indicated relative financial incapacity of some elders of the community towards community development programmes. The study further stressed that few members of the communities have adequate financial resources to cope with feeding, education, clothe to say the least. Hence, the limited capacity of rural communities in this respect hindered the acceleration of community development programmes.

On government inability to complement community development programmes, Abisoye (2008) buttressed the findings that government had not touched on the communities' most pressing needs, regardless of solving the problem. It was, therefore, stressed that many of the development projects being executed by the government are being merely forced on the people. This may therefore, explain why there are many abandoned projects all around because the zeal to supplement government efforts would naturally be lacking in the people who do not count a project to be of relevance to their social life.

The findings revealed that political instability affects government assistance to the community. This involves frequent changes in government in Nigeria which has affected government policy. A new administration will prefer to start her own policy of development instead of furthering the previous administration's programmes. This is one of the problems identified by Abiona (2009) confronting community development. Therefore, it has major implication for the sustainability of community development programmes.

\section{Conclusions}

Grassroots participation in development programmes and decision-making process play a vital role in community development programmes. Local participation being at the heart of a people centred development paradigm looks up to empowerment and people's sovereignty as the defining principles of authentic sustainable development. Development in such circumstance becomes a people's movement and providing people with the opportunity and environment for self-sustaining development. Therefore, this study was set to fill this gap by attempting an empirical study on this issue, and in this regard had carried out analysis of grassroots participation and decision-making process in community development programmes. Grassroots participation in development programmes and decision-making process have been established to be a vital tool which facilitated sustainability of community development programmes.

\section{Recommendations}

(i) Sustainability of community development programmes requires integration of the people in the process. There is need for mobilization of community stakeholders to be involved in decision making, planning, implementation, monitoring and evaluation of programmes.

(ii) Achieving sustainability requires a lot attitudinal change and interest. This calls for raising the consciousness and awareness of all community stakeholders in the process. This entails provision of education through dissemination of information to enhance the capacity of the community members for effective sustainability of community development programmes.

(iii) From the study, sustainability of community development programmes has been marred with many challenges. This needs government's attention for the provision of financial support, eradicating communal clashes, addressing problem of frequent changes in government policy and ensure transparency and accountability. 


\section{References}

Abiona, I. A. (2009). Principles and Practice of Community Development (pp. 17-81). Ibadan University Press.

Abisoye, A. O. (2008). Participation and Democracy: Implication for Community Development in Oyo State, Nigeria. (Ph.D thesis Department of Sociology, University of Ibadan, Ibadan).

Abu, P. B., \& Oghenekohwo, J. E. (2003). Citizens Participation in Community Development in Developing Countries. International Journal of Continue and Non-Formal Education, 2(1), 63.

Adedokun, O. M. (1998). The Contributions of Community Education to Sustainable Community Development Project in Oyo state, (1987-1996). (Ph.D thesis Department of Adult Education, University of Ibadan., Ibadan).

Adegboye, M. A. (2005). Sources of Motivation to Rural Dwellers Participation in Self-help Projects in Plateau States, Nigeria. Ph.D Thesis Department of Agricultural Extention and Rural Development, University of Ibadan., Ibadan.

Akinboade, C. Y. (1994). The Effects of Women Empowerment on Participation in Community- based Development Projects in Ondo and Kogi States Nigeria 1986-1994. (Ph.D thesis, Department of Adult education, University of Ibadan. Ibadan).

Akintayo, M. O., \& Ogbenekohwo, J. E. (2004). Developing Adult Education and Community Development: New Paradigms, Ibadan, Educational Research and Study Group.

Akinyemi, V. I. (1994). Determinants of Citizen Participation in Community Development Activities in Ondo state. Ph.D Thesis, Department of Adult Education, University of Ibadan.

Akoroda, O. (2012). Citizen Participation in Self-Help Projects and Socio- Economic Development in Communities in Delta and Oyo States. (Unpublished Ph.D thesis, University of Ibadan, Nigeria).

Anyanwu, C. N. (1981). Principles and Practice of Adult Education and Community Development. (pp. 189-194) Ibadan, Abiprint Publishing Company Limited.

Anyanwu, C. N. (1992). Community Development: The Nigerian Perspective, Ibadan, Gabesther Educational Publishers.

Babajide, O. O. (2006). Rural Change and the Impact of Development Intervention on Ilaje People in Ondo State, Nigeria. (Unpublised Ph.D thesis, Institute of African Studies, University of Ibadan, Ibadan).

Babashola. (1998). Nigerian Human Development Report UNDP. Reports, Lagos, in Nigeria.

Bird, P. (1997). Funder or Founder: The Role of Development Agencies in Shared Forest Management Commonwealth. Forestry Review, 76(3), 40-49.

Community Development Agency. (2007). National Community Development Policy, Abuja.

Dusautoy, P. (1962). The Organization of a Community Development Programmes. London Oxford University Press.

Eboh, E. C., Okoye, C., \& Ayichi, D. (1995). Rural Development in Nigeria: concepts, process and prospects. Enugu Auto-century publishing company.

Egenti, M. N. (2001). The influence of citizen participation in self-help projects on the welfare of people in Imo state, Nigeria. (Unpublished Ph.d Thesis, University of Ibadan).

Maureen, N. E. (2005). Appraisal of the Due Process in The Principles, Methods and Techniques of Managing Community Development Projects for Development in Adult and Non-Formal Education in Nigeria: Ibadan Emerging Issues, papers from the NNCAE Annual Conference. p16.

National Strategies for Sustainable Development. (1998). Nepal Sustainable Community Development Programmes. Retrieved from www.nnssd.net

Obianigwe. (1999). Talking Rural Development. Vanguard Monday, March $18^{\text {th }}, 1999$.

Olaniyi, W. O. (2000). School Community Relations in the $21^{\text {st }}$ Century. In J. O. Fadipe, \& Oluchukwu (Eds), Educational Planning and Administration in Nigeria in the $21^{\text {st }}$ Century, Ibadan, National Institute For Educational Planning and Administration .

Olasupo, F. A. (2000). Community Participation in Governance and Development in Nigeria in Akpomuvire Mukoro Institutional Administration: A Contemporary Local Government Perspective from Nigeria (p. 169). Lagos: Malthouse Press Limited. 
Omotola, S. J. (2006). No democracy, No Development or Vice-Versa? In F. Hassan, L. Jacob, Usman, \& Samuel (Eds), Democracy and Development in Nigeria: Conceptual Issues and Democratic Practice (p. 29). Lagos: Concepts Publishing Limited.

Onabanjo, F. A. (2004). Community Development: Rural Development and Planned Social Change (pp. 1-44). Lagos, Felix Enterprises.

Osaghae, E. E. (1999). Ethnicity and its management in Africa. Lagos: Malthouse Press Limited.

Osuji, E. E. (1991). Enhancing the Quality of Community Development Projects. In A. Gbolagade \& F. Theodocia (Eds.), Improving the quality of community Development Projects in Nigeria.

Osuji, E. E. (1992). Community Participant: Proceeding of Unicef Sponsored Workshop. University of Ibadan, Consultancy Services Unit.

Otite, R. E. (2002). Partnering in Community Development: A Study of Three Rural Communities in Delta State Nigeria (p. 114). (Thesis Department of Adult Education, University of Ibadan, Ibadan).

Otive, I. (2006). Review of Nigeria Millennium Development Goals-2005 Report.

Oyelami, R. O. (2007). Community Participation and Performance in Secondary Schools in Oyo and Osun States,igeria. (Unpublished Ph.d Thesis university of Ibadan).

Paul, S. (1999). Community Participation in Development Projects. The World Bank Experience in Researching Community Development Institute Workshop. A Community participation, September, 1997 Washington, DC.

Sarumi, A. (2003). Community Development: Historical Perspective in the Nigeria Journal and Labour Relations. University of Ibadan.

Ugwu, S. C. (2000). Issues in local government and urban administration in Nigeria. Enugu Academic Printing Press.

UNDP. (1999). Indicators of Sustainable Development, Interim Analysis World Bank, 2008: Community and Social Development Project in Nigeria. Retrieved August 27, 2011, from http//www.worldbank.org

World Bank. (2001). Retrieved from www.decentralization.org

World Bank, Group. (2011). Social Aspect of Sustainable Development in Nigeria. Retrieved August 27, 2011, from http//www.worldbank.org

World Bank Report. (2001). Concept of decentralization. Retrieved July 20, 2011, from www.decentralization.org 